\title{
TUBERKULOSIS INTRAOKULAR
}

\section{Prilly Astari}

Fakultas Kedokteran Universitas Gadjah Mada, Yogyakarta, Indonesia

Correspondence author:

\section{Prilly Astari}

Fakultas Kedokteran Universitas Gadjah Mada, Yogyakarta, Indonesia

Email: prillyastari@yahoo.com

\section{Article Info:}

Received: 22 June 2018

Revised: 17 June 2019

Accepted: 19 July 2019

Available online: 31 July 2019

Keywords: choroiditis, immunology, infection, tuberculosis, uveitis

DOI: $10.20956 / n m s j . v 4 i 1.4684$

\begin{abstract}
Tuberculosis (TB) is an infectious disease caused by the bacteria, Mycobacterium tuberculosis. TB typically affects the lungs, but it can also affect other organs, including the eyes. Infection by Mycobacterium tuberculosis inside the eye is called intraocular TB. There are several controversies related to the terminology, diagnosis, and therapy that result in varying prevalence of intraocular TB, different selection of diagnostic tests, and different duration of Anti-TB therapies.
\end{abstract}

\section{PENDAHULUAN}

Tuberkulosis (TB) adalah suatu penyakit menular yang disebabkan oleh kuman dari kelompok Mycobacterium yaitu Mycobacterium tuberculosis. ${ }^{1}$ TB paling banyak menyerang organ paru-paru, namun sekitar $20 \%$ dapat melibatkan organ tubuh lainnya, termasuk lesi pada saluran gastrointestinal, saluran genitourinarius, sistem kardiovaskular, kulit, sistem saraf pusat, dan mata. Keterlibatan sistem ekstra paru dapat terjadi bersamaan dengan infeksi TB paru atau dapat terjadi tanpa infeksi TB paru. Faktor risiko terjadinya TB ekstra paru, termasuk TB okular, adalah infeksi HIV, usia muda, jenis kelamin perempuan, dan ras non kulit putih..$^{2-4}$ TB okular didefinisikan sebagai infeksi oleh Mycobacterium tuberculosis di mata, di sekitar mata, atau pada permukaan mata. ${ }^{3}$ Angka kejadian TB okular dilaporkan sekitar $1,4 \%-18 \%$ dari seluruh pasien TB paru dan $7 \%-10,5 \%$ dari seluruh pasien uveitis. ${ }^{2,5}$. TB okular dapat mengenai bilik depan mata, iris, korpus siliaris, vitreus, koroid yang disebut TB intraokular dan struktur di sekitarnya seperti orbital, konjungtiva, glandula lakrimalis, kornea, sklera yang disebut TB ekstraokular. Terdapat beberapa kontroversi terkait TB okular dalam hal terminologi, diagnosis, dan terapi yang mengakibatkan prevalensi TB okular sangat beragam, pemilihan tes diagnostik yang berbedabeda, dan durasi terapi Obat Anti Tuberkulosis (OAT) yang berbeda - beda. ${ }^{5}$

\section{Epidemiologi}

Kejadian TB okular pada pasien TB paru dilaporkan terjadi antara $1,4 \%$ dan $18 \% .^{2}$ Pada pasien dengan HIV, insiden TB okular meningkat hingga $2,8-11,4 \%$. Studi lain melaporkan jumlah TB okular adalah sekitar 7\% - 10,5\% dari seluruh pasien uveitis. ${ }^{5}$ Namun, sampai saat ini, tidak ada data akurat mengenai prevalensi TB okular yang sebenarnya. Hal ini disebabkan oleh karena kriteria diagnostik yang berbeda-beda, penggunaan istilah 'probable' dan 'possible' TB, gejala yang tidak khas, pengambilan sampel yang sulit, dan metode laboratorium dengan sensitifitas atau spesifisitas yang rendah. ${ }^{6-8}$ 


\section{Patogenesis}

Mycobacterium tuberkulosis (MTB) masuk

ke dalam saluran pernafasan melalui droplet dan sampai di alveolus dimana terdapat makrofag dan dendritik sel. Proses berikutnya adalah fagositosis MTB oleh makrofag dan dendritik sel. Makrofag dan dendritik sel kemudian mengeluarkan sitokin proinflamatori seperti IL-12 dan IL-18. Proses inflamasi ini memicu datangnya monosit dan memfagositosis kuman yang masih hidup. Di dalam makrofag, MTB menghambat pertemuan antara fagosom dan lisosom sehingga makrofag hancur sedangkan MTB bertumbuh. TNF- $\alpha$ terbentuk dan memicu respon hipersensitivitas tipe lambat yang akan menghancurkan makrofag dengan MTB di dalamnya. Sebagai hasilnya, akan terbentuk sentral nekrosis kaseosa yang dikelilingi oleh makrofag aktif, sel T, dan sel imun lainnya. Jika respon imun tubuh buruk, maka MTB dapat bermultiplikasi dan beberapa akan masuk ke dalam sistem limfatik dan sirkulasi menuju ke organ - organ lain, termasuk mata. Sebaliknya, jika respon imun tubuh baik, maka MTB akan dimakan oleh sel $\mathrm{T}$ sebelum dapat bermultiplikasi dan menyebar. Setelah sampai di organ mata, MTB dapat langsung aktif dan menimbulkan gejala klinis, namun dapat juga memasuki fase dorman selama bertahun - tahun dan bisa menjadi aktif kapan saja.-8.

\section{Klasifikasi}

\section{a. Klasifikasi Anatomis}

TB okular dapat dibedakan menjadi TB intraokular dan TB ekstraokular. TB intraokular melibatkan struktur bola mata seperti traktus uvea. Traktus uvea adalah lapisan pigmen bola mata yang terletak di antara sklera dan retina dan mengandung banyak pembuluh darah. Traktus uvea terdiri dari tiga bagian yaitu iris, korpus siliaris, dan koroid. Jika terjadi peradangan di traktus uvea, pada kasus ini yang disebabkan oleh kuman MTB, hal ini dinamakan uveitis TB. Berdasarkan lokasi anatomis terjadinya peradangan, uveitis dapat dibedakan menjadi uveitis anterior dimana peradangan terjadi di bilik depan mata dan iris, uveitis intermediate dimana peradangan terjadi di korpus siliaris dan vitreus, uveitis posterior dimana peradangan terjadi di retina dan koroid, dan panuveitis dimana peradangan terjadi di seluruh bagian traktus uvea. $^{7,9}$ TB ekstraokular melibatkan struktur di sekitar bola mata, seperti jaringan lunak orbita, konjungtiva, glandula lakrimalis, kornea, dan sklera.

$$
\text { - TB intraokular }{ }^{7,9}
$$

a) Uveitis anterior

Pasien dengan uveitis anterior datang dengan keluhan mata merah, buram, nyeri, fotofobia, dan dapat terjadi unilateral atau bilateral. Pada pemeriksaan, kita dapat menemukan keratik presipitat granulomatosa, sel di bilik depan mata, iris granuloma, sinekia posterior luas, nodul berwarna abu-abu hingga kuning, yang terkadang disertai oleh hipopion.

b) Uveitis intermediate

Berbeda dengan uveitis anterior yang menimbulkan gejala mata akut, pasien dengan uveitis intermediate datang dengan keluhan mata buram dan floater. Seperti telah disebutkan sebelumnya, jika peradangan terjadi di korpus siliaris posterior maka dinamakan siklitis posterior dan jika terjadi di vitreus maka dinamakan vitritis. Pada pemeriksaan, kita dapat menemukan sel radang dan kekeruhan di vitreus.

c) Uveitis TB posterior dan panuveitis Koroid sebagai struktur dari bola mata yang terdiri dari banyak pembuluh darah sehingga penyebaran MTB secara hematogen dapat terjadi di sana. Apabila hal ini terjadi, maka MTB dapat menyebabkan peradangan di koroid yang disebut uveitis TB posterior.

d) Retinitis dan vaskulitis retina

TB intraokular dapat mengenai retina dan pembuluh darah retina yang masing - masing disebut sebagai retinitis dan vaskulitis retina. Jika peradangan melibatkan pembuluh darah retina, biasanya berkaitan dengan penyakit sistemik. Pada pemeriksaan, kita dapat menemukan akumulasi benda berwarna keputihan mengelilingi arteri atau vena retina yang dinamakan periphlebitis dan merupakan karakteristik dari vaskulitis TB. Selain periphlebitis, kita juga akan menjumpai satu atau lebih tanda seperti vitritis, perdarahan retina, neovaskularisasi, dan neuroretinitis.

e) Neuroretinitis dan neuropati optik Kuman MTB menyerang saraf mata dengan cara menginfeksi langsung, 
penyebaran dari koroid, penyebaran melalui hematogen dari paru - paru atau fokus infeksi primer lainnya, atau reaksi hipersensitivitas terhadap kuman MTB. Pada pemeriksaan, kita dapat menjumpai manifestasi seperti tuberkel nervus optikus, papillitis, papilledema, neuritis optikus, neuritis retrobulbar, dan neuroretinitis. Neuroretinitis ditandai dengan edema diskus optikus.

f) Endoftalmitis dan panoftalmitis Uveitis anterior, intermediate, dan posterior jika tidak diobati dengan OAT yang adekuat dapat berlanjut menjadi endoftalmitis dan panoftalmitis. Pada kasus endoftalmitis, kita dapat menemukan kekeruhan di kavitas vitreus. Pada kasus panoftalmitis, kita dapat menemukan tanda - tanda endoftalmitis disertai dengan keterlibatan sklera dan sebagai akibatnya dapat menyebabkan perforasi mata.

\section{b. Klasifikasi Diagnosis}

Selain dibedakan berdasarkan lokasi anatomis terjadinya peradangan, TB okular dapat dibedakan berdasarkan kriteria diagnosis. Dari tabel dibawah ini, jika terdapat satu atau lebih tanda - tanda klinis dari A ditambah dengan salah satu hasil tes positif dari B disebut confirmed TB intraokular. Jika terdapat satu atau lebih tanda tanda klinis dari A ditambah dengan salah satu hasil tes positif dari $\mathrm{C}$ atau perbaikan dengan OAT seperti tertulis di D maka disebut presumed TB intraokular. ${ }^{10}$

A. Tanda - tanda klinis

a. Terdapat reaksi sel di bilik depan mata dan atau vitreous dengan atau tanpa sinekia posterior

b. Tampakan bola salju opasitas pada vitreous inferior

c. Perselubungan perivaskular oleh eksudat inflamasi

d. Granuloma koroid tunggal atau multifokal dengan atau tanpa eksudatif ablasi retina

e. Granuloma diskus optikus dengan atau tanpa neuroretinitis

f. Abses subretina

B. Pemeriksaan penunjang lokal

a. Ditemukan BTA atau kultur $M$. tuberkulosis dari cairan okular

b. PCR positif untuk M. tuberkulosis dari cairan okular

\begin{tabular}{|c|c|c|}
\hline & & $\begin{array}{l}\text { Tes Mantoux positif } \\
\text { X-ray thorax menggambarkan lesi aktif } \\
\text { atau non-aktif TB } \\
\text { Terdapat bukti TB ekstra paru yang } \\
\text { didiagnosis dengan adanya granuloma } \\
\text { TB/BTA/kultur M. tuberkulosis }\end{array}$ \\
\hline D. & $\begin{array}{l}\mathrm{Te} \\
\mathrm{Re} \\
6 \mathrm{n}\end{array}$ & $\begin{array}{l}\text { orapeutik } \\
\text { on positif terhadap OAT selama } 4 \text { sampai } \\
\text { nggu }\end{array}$ \\
\hline
\end{tabular}

\section{Tabel 1. Kriteria diagnosis TB intraokular}

Selain kriteria diagnosis diatas, terdapat kriteria diagnosis lainnya yang lebih mudah digunakan adalah dengan membagi TB intraokular menjadi tiga kelompok, yaitu confirmed, probable, dan possible TB intraokular. $^{9}$

\begin{tabular}{|c|c|}
\hline A. & $\begin{array}{l}\text { Confirmed TB intraokular: } \\
\text { 1. Terdapat satu atau lebih tanda klinis TB } \\
\text { intraokular } \\
\text { 2. Konfirmasi mikrobiologi M. tuberkulosis } \\
\text { dari cairan/jaringan okular }\end{array}$ \\
\hline & $\begin{array}{l}\text { Probable TB intraokular: } \\
\text { 1. Terdapat satu atau lebih tanda klinis TB } \\
\text { intraokular (dan eksklusi penyebab lain) } \\
\text { 2. X-ray thorax menggambarkan lesi TB atau } \\
\text { bukti klinis TB ekstraokular atau } \\
\text { konfirmasi mikrobiologi dari sputum atau } \\
\text { organ - organ ekstraokular }\end{array}$ \\
\hline
\end{tabular}

3. Salah satu dari :

a. Terdapat riwayat terpapar TB dalam 24 bulan terakhir

b. Bukti imunologis (Tes Mantoux / IGRA / PCR) yang positif menunjukkan infeksi TB

C. Possible TB intraokular :

1. Terdapat satu atau lebih tanda klinis TB intraokular (dan eksklusi penyebab lain)

2. X-ray thorax tidak konsisten dengan infeksi TB dan tidak ada bukti klinis TB ekstraokular

3. Salah satu dari :

c. Terdapat riwayat terpapar TB dalam 24 bulan terakhir

d. Bukti imunologis (Tes Mantoux / IGRA / PCR) yang positif menunjukkan infeksi TB

ATAU

1. Terdapat satu atau lebih tanda klinis TB intraokular (dan eksklusi penyebab lain)

2. X-ray thorax konsisten dengan infeksi TB atau bukti klinis TB ekstraokular tetapi tidak terdapat riwayat terpapar TB dalam 24 bulan terakhir dan tidak terdapat bukti imunologis (Tes Mantoux / IGRA / PCR) yang positif menunjukkan infeksi TB

Tabel 2. Kriteria diagnosis TB intraokular

\section{Penegakan diagnosis}

\section{a) Anamnesis}

Beberapa hal yang perlu ditanyakan kepada pasien adalah :

Keluhan utama, onset, mata kanan atau kiri, 
durasi, keluhan tambahan, keluhan khas TB paru (batuk lama berdahak, demam subfebris, keringat malam hari, penurunan berat badan), riwayat kontak dengan penderita $\mathrm{TB}$, riwayat $\mathrm{TB}$ dan pengobatan TB sebelumnya, riwayat infeksi, riwayat konsumsi obat - obatan, gejala mata buram, floater, fotofobia.

\section{b) Pemeriksaan fisik}

Pada pemeriksaan fisik mata dapat ditemukan tanda-tanda sebagai berikut : adanya sel di bilik depan mata atau vitreous bersamaan dengan ditemukannya ${ }^{9}$

(1) Sinekia posterior yang luas

(2) Perivasculitis retina dengan atau tanpa koroiditis atau luka yang diskrit

(3) Koroiditis serpiginoid multifokal

(4) Granuloma koroid (tunggal atau multifokal)

(5) Granuloma diskus optikus

(6) Neuropati optik

\section{c) Pemeriksaan penunjang}

- X-ray thorax : pemeriksaan x-ray thorax perlu dilakukan untuk melihat lesi TB pada paru - paru sebagai organ yang paling sering terkena TB. Pemeriksaan ini dapat dilakukan walaupun dilaporkan bahwa hasil x-ray normal pada $70 \%$ pasien. ${ }^{6}$

- Polymerase Chain Reaction (PCR) : pemeriksaan PCR menggunakan cairan akuos dapat mendeteksi MTB dengan sensitivitas $77,77 \%$ dan spesifisitas $100 \% .^{11}$

- Kultur : TB intraokular adalah penyakit paucibacillary dan hampir tidak mungkin untuk berhasil mendapatkan sampel dari cairan atau jaringan intraokular. Sebagai hasilnya, kultur sangat jarang dapat menunjukkan MTB. ${ }^{9}$

- Tes Mantoux : hasil positif didefinisikan sebagai diameter indurasi lebih dari $10 \mathrm{~mm}$ pada pasien tanpa HIV dan lebih dari $5 \mathrm{~mm}$ pada pasien $\mathrm{HIV}^{9}$ dengan sensitivitas $71 \%$ dan spesifisitas $66 \%{ }^{12}$ Tes Mantoux tidak dapat membedakan infeksi TB aktif dan TB laten. Pada beberapa negara berkembang, tes ini masih rutin dilakukan sebagai bagian dari pemeriksaan penunjang untuk TB.

- Interferon-Gamma Release Assays (IGRA) seperti QuantiFERON-TB gold test : sensitivitas dan spesifisitas mencapai $58 \%$ dan $77 \%$ dalam mendiagnosis TB paru aktif dan $82 \%$ dan $76 \%$ dalam mendiagnosis TB intraokular. ${ }^{13}$ IGRA tidak dapat membedakan infeksi TB aktif dan TB laten dan sering menimbulkan hasil positif palsu.

\section{d) Rujukan}

Semua pasien dengan diagnosis TB okular harus dirujuk ke bagian lain untuk mencari

kemungkinan asosiasi infeksi yang mungkin ada di tempat lain.

\section{Terapi}

Seluruh pasien TB okular (baik intraokular maupun ekstraokular) perlu untuk dikonsultasikan dengan spesialis penyakit infeksi/Spesialis Paru/Internis sebelum memutuskan regimen terapi. ${ }^{6,7}$ Pengobatan untuk TB okular hampir sama dengan pengobatan pada TB ekstraparu yaitu dengan menggunakan obat OAT dengan rentang waktu tertentu. Penelitian membuktikan penggunaan OAT selama 9 bulan menurunkan angka rekurensi uveitis TB sebanyak 11 kali. $^{14}$ Penelitian lainnya juga menyebutkan penggunaan OAT menurunkan angka rekurensi uveitis TB sebanyak 2 kali. $^{15}$

Lokal

Pemberian obat topikal dapat diberikan steroid dan sikloplegik untuk pengobatan pada uveitis. ${ }^{16}$

\section{Sistemik}

Terdapat beberapa kontroversi dalam tatalaksana TB okular seperti durasi pemberian obat anti tuberkulosis (OAT) dan pemberian sistemik kortikosteroid. Apakah TB okular merupakan infeksi yang sesungguhnya pada mata atau terkait reaksi sistemik tersembunyi dari infeksi TB, setidaknya diketahui bahwa OAT dapat menurunkan risiko berkembangnya $\mathrm{TB}$ aktif $80 \%-90 \%$ pada mereka yang menderita infeksi TB laten. ${ }^{6}$

a.) Obat Anti Tuberkulosis

Hingga saat ini, belum terdapat konsensus untuk pengobatan TB okular. Pada studi terbaru melaporkan penggunaan sedikitnya satu dan sebanyak-banyaknya 4 macam OAT dengan rentang pengobatan mulai dari 6 bulan sampai 18 bulan. Pengobatan kombinasi yang terdiri dari pyrazinamid, etambutol, isoniazid dan rifampin sangat dianjurkan. Dua macam OAT dihentikan setelah 2-3 bulan, dan pengobatan dilanjutkan selama 9-12 bulan kedepan dengan menggunakan isoniazid dan rifampin. ${ }^{7}{ }^{16}$ Pada penelitian Gupta et al, pada 150 pasien dengan TB okular mendapat terapi OAT antara 6 sampai 15 bulan, didapatkan sekitar $95 \%$ dari pasien didapatkan respon terhadap pengobatan dengan terjadinya resolusi pada peradangan intraokular. ${ }^{7}$ Pada studi 
dimana pasien yang merespon terhadap OAT, perbaikan terjadi diantara 2 minggu sampai 3 bulan. Pada pasien yang merespon dalam 2 bulan mungkin akan bermanfaat pada terapi OAT selama 6 bulan. Sedangkan pada pasien yang tidak ada respon pada 2-3 bulan pertama, perlu dipertimbangkan pemberian terapi lini kedua atau mengganti terapi melalui pertimbangan status kesehatan keseluruhan pasien dan konsultasi dengan spesialis penyakit infeksi. ${ }^{17}$

b.) Kortikosteroid

Pemberian steroid pada tuberkulosis okular direkomendasikan, namun hingga saat ini belum ada data dari clinical trial mengenai terapi tersebut. Pemberian steroid sistemik direkomendasikan pada kondisi inflamasi okular yang persisten dan vaskulitis retina. Pada sebuah literatur disebutkan bahwa pemberian terapi steroid bersama dengan OAT menunjukkan hasil luaran yang lebih baik bila dibandingkan dengan pemberian OAT semata. Prednison oral dapat diberikan dengan tujuan mengontrol reaksi inflamasi dan mengurangi edema makula selama 4-6 minggu. Pemberian steroid mulai diturunkan perlahan setelah 6 minggu. Pemberian terapi steroid dapat ditunda untuk melihat respon penderita terhadap OAT, akan tetapi keputusan ini harus berdasarkan penilaian risiko kehilangan penglihatan. Pemberian steroid tunggal tanpa OAT harus dihindari karena dapat menyebabkan multiplikasi kuman basili yang dapat menyebabkan panoftalmitis atau dapat memunculkan kembali TB sistemik akibat dari aktivasi infeksi. ${ }^{7,16}$

c.) Imunosupresan

Pengobatan utama TB okular adalah OAT dan sistemik steroid. Pada beberapa kasus, seperti serpiginous-like choroiditis, pengobatan maksimal dengan OAT dan sistemik steroid tetap menunjukkan inflamasi yang menetap atau bahkan memburuk dan sering kambuh. Oleh sebab itu, kita dapat menambahkan imunosupresan, seperti Azatioprin dengan dosis awal 1 $\mathrm{mg} / \mathrm{kgBB} /$ hari (maksimal 2,5 -4 $\mathrm{mg} / \mathrm{kgBB} /$ hari) dalam dosis tunggal atau terbagi dua. Dalam pemberian Azatioprin, kita perlu memperhatikan efek samping dari Azatioprin yaitu supresi sumsum tulang, gangguan gastrointestinal, dan hepatotoksik, sehingga kita perlu memeriksakan darah lengkap dan hitung trombosit setiap 4 minggu dan fungsi hati setiap 12 minggu. Kita harus menghentikan pemberian Azatioprin jika total sel darah putih kurang dari $3.500 \mathrm{sel} / \mathrm{mm}^{3}$, trombosit kurang dari $100.000 \mathrm{sel} / \mathrm{mm}^{3}$, atau enzim hati lebih dari 5 kali jumlah normal. ${ }^{18,19}$

\section{Komplikasi}

TB intraokular dapat menyebabkan beberapa komplikasi seperti glaukoma sekunder, katarak sekunder, sinekia posterior, perdarahan vitreus, dan Cystoid Macular Edema (CME). ${ }^{7,20}$

\section{Simpulan}

Mycobacterium tuberculosis dapat menyerang mata dan mengakibatkan tuberkulosis intraokular. Sampai saat ini, tidak ada data akurat mengenai prevalensi TB intraokular yang sebenarnya karena terdapat beberapa kontroversi dalam hal terminologi, diagnosis, dan terapi. TB intraokular dapat dibedakan berdasarkan lokasi anatomis maupun kriteria diagnosis. Penegakan diagnosis membutuhkan anamnesis, pemeriksaan fisik, dan pemeriksaan penunjang yang tepat. TB intraokular diterapi dengan OAT, kortikosteroid, dan imunosupresan. Jika tidak diobati atau pengobatan tidak adekuat, TB intraokular dapat menyebabkan komplikasi yang serius.

\section{DAFTAR PUSTAKA}

1. Kementerian Kesehatan RI. 2014. Pedoman Nasional Pengendalian Tuberkulosis. Direktorat Jenderal Pengendalian Penyakit Dan Penyehatan Lingkungan. Jakarta.

2. Pollett S, Banner P, O'Sullivan MV, Ralph AP. Epidemiology, Diagnosis and Management of Extra-Pulmonary Tuberculosis in a Low-Prevalence Country: A Four Year Retrospective Study in an Australian Tertiary Infectious Diseases Unit. PloS one 2016;11:e0149372.

3. Yang Z, Kong Y, Wilson F, et al. Identification of risk factors for extrapulmonary tuberculosis. Clin Infect Dis 2004;38:199-205. 
4. Cailhol J, Decludt B, Che D. Sociodemographic factors that contribute to the development of extrapulmonary tuberculosis were identified. J Clin Epidemiol 2005;58:1066- 71.

5. Vos AG, Wassenberg MW, de Hoog J, et al. Diagnosis and treatment of tuberculous uveitis in a low endemic setting. Int J Infect Dis 2013;17:e993-9.

6. Ang M, Chee S-P. Controversies in ocular tuberculosis. $\mathrm{Br} \quad \mathrm{J}$ Ophthalmol 2017;101:6-9.

7. Gupta V, Gupta A, Rao NA. Intraocular tuberculosis--an update. Survey of ophthalmology 2007;52:561-87.

8. Sharma A, Thapa B, Lavaju P. Ocular tuberculosis: an update. Nepal J Ophthalmol 2011:3(5):52-67.

9. Gupta A, Sharma A, Bansal R, Sharma K. Classification of intraocular tuberculosis. Ocul Immunol Inflamm 2015;23:7-13.

10. Agrawal R, Gonzalez-Lopez JJ, NobreCardoso J, et al. Predictive factors for treatment failure in patients with presumed ocular tuberculosis in an area of low endemic prevalence. Br J Ophthalmol 2016;100:348-55.

11. Sharma K, Gupta V, Bansal R, et al. Novel multi-targeted polymerase chain reaction for diagnosis of presumed tubercular uveitis. J Ophthalmic Inflamm Infect. 2013;3:25.

12. Targeted tuberculin testing and treatment of latent tuberculosis infection. American Thoracic Society. MMWR Recomm Rep 2000;49:1-51.

13. Babu K, Satish V, Satish S, et al. Utility of QuantiFERON TB gold test in a south Indian patient population of ocular inflammation. Ind $\mathrm{J}$ Ophthalmol. 2009;57:427-430.

14. Ang M, Hedayatfar A, Wong W, Chee SP. Duration of anti-tubercular therapy in uveitis associated with latent tuberculosis: a case-control study. $\mathrm{Br} \mathrm{J}$ Ophthalmol 2012;96: 332-336.

15. Bansal R, Gupta A, Gupta V, Dogra MR, Bambery P, Arora SK. Role of AntiTubercular Therapy in Uveitis with latent/manifest tuberculosis. Am J Ophthalmol 2008;146:772-779.

16. Oluleye, T. Tuberculous Uveitis. Journal of Multidisciplinary Healthcare 2013:6 41-3.
17. Kee AR, Gonzalez-Lopez JJ, Al-Hity A, Gupta B, Lee CS, Gunasekeran DV, Jayabalan N, Grant R, Kon OM, Gupta V, Westcott M, Pavesio C, Agrawal R, Anti tubercular therapy for intraocular tuberculosis: A systematic review and meta analysis, Survey of Ophthalmology (2016), doi: 10.1016/j.survophthal.2016.03.001.

18. Babu K, Mahendradas P. Medical Management of Uveitis - Current Trends. Indian Journal of Ophthalmology. 2013;61(6):277-283. doi:10.4103/03014738.114099 .

19. Bansal R, Gupta V, Gupta A. Current approach in the diagnosis and management of panuveitis. Indian Journal of Ophthalmology. 2010;58(1):45-54. doi:10.4103/03014738.58471 .

20. Basu et al. Degree, duration, and causes of visual impairment in eyes affected with ocular tuberculosis. Journal of Ophthalmic Inflammation and Infection 2014,4:3. 